\title{
Sistem Informasi Inventory Barang Menggunakan Metode Fifo Pada Pt. Exelindo Bintan Sahtera Tanjungpinang
}

\author{
Ricak Agus Setiawan ${ }^{1}$, Shelvy Sofiana ${ }^{2}$, Titania Pricillia ${ }^{3}$ \\ ${ }_{1,2,3}$ STT Indonesia Tanjungpinang \\ ${ }^{1}$ ricak.agus@gmail.com, ${ }^{2}$ shelvysoviana123@gmail.com, ${ }^{3}$ titania@sttindonesia.ac.id
}

\begin{abstract}
Abstrak
Semakin berkembangnya zaman, dunia teknologi semakin canggih. Seluruh informasi yang ingin diperoleh dapat dengan mudah kita dapatkan. Akses internet semakin cepat dan dunia software mengalami kemajuan yang sangat pesat. Kemajuan ini harus didasari dengan kemajuan ilmu teknologi yang seimbang, salah satunya dengan melahirkan programmer yang handal. PT exelindo memiliki kegiatan yang cukup amat pesat,dari mulai orderan ,pemasukan barang hingga pengeluaran barang. Pengolahan data stok barang untuk sekarang masih manual, sehingga pemilik tidak mengetahui stok lama yang masih tersedia.Oleh karna itu dibuatlah satu aplikasi yang bisa membantu pemilik serta para karywannya dalam mengolah data,serta jumlah barang yang tersedia. Tools yang digunakan sebagai alat bantu dalam penelitian ini adalah menggunakan Tools Netbeans dan Database manajemen Menggunakan Sistem MySQL.
\end{abstract}

Kata Kunci: sistem informasi, FIFO, Inventory.

\begin{abstract}
With the development of the times, the more sophisticated world of technology. All information that we want can be obtained easily. Internet access is getting faster and the software world is progressing very rapidly. This progress must be based on balanced advances in technology, one of which is by producing reliable programmers. PT Exelindo has quite rapid activities, from ordering, importing goods to releasing goods. Stock processing for now is still manual, so the owner does not know the old stock that is still available. Therefore, an application is made that can help the owner and his employees in processing the data, as well as the number of items available.

Tools that are used as assistive tools in this research are using Netbeans Tools and Database management Using MySQL Systems.
\end{abstract}

Keywords: information systems, FIFO, Inventory.

\section{Pendahuluan}

\subsection{Latar Belakang}

PT. Exelindo Bintan Sejahtera adalah salah satu perusahaan yang tedapat di kota Tanjungpinang yang terletak di Jl. Brigjend Katamso No. 20-21, yang bergerak dibidang penjualan alat-alat elektronik. Untuk saat ini dalam melakukan pengelolaan ketersediaan barang pada PT. Exelindo Bintan Sejahtera masih belum optimal, Seperti sering terjadi pada beberapa barang elektronik yang di order, sudah lama ada namun hingga sekarang belum terjual karna stok yang lama kurang laku dibandingkan dengan stok yang baru. Kerugian yang dialami oleh perusahaan dikarenakan hal ini tidaklah sedikit,Permasalahan juga terletak pada barang elektronik yang jika lama tidak terjual bisa memicu kerusakan pada barang elektronik tersebut hingga penurunan harga yang drastis.Dan untuk menambah ketersediaan barang,karyawan harus mengecek satu persatu barang mana yang habis menggunakan aplikasi gf akuntansi,hal ini disebabkan ketiadaannya fungsi filter pada aplikasi ini, sehingga apabila ingin mengecek stok secara banyak dan berdasarkan merk tertentu atau tanggal tertentu, aplikasi ini tidak mampu melakukannya. Hal ini tentu sangat mempengaruhi kinerja pihak manajemen dalam melakukan pengelolaan inventory barang. ${ }^{1}$

\subsection{Identifikasi Masalah}

Berdasarkan latar belakang, maka identifikasi masalah yang muncul diantaranya:

1. Sistem Pengelolaan data barang yang belum menggunakan metode sehingga kurang dapat mengelola persediaan barang.

2. Proses pembuatan laporan data barang yang belum terperinci

\subsection{Rumusan Masalah}

Berdasarkan identifikasi permasalahan di atas maka terdapat rumusan masalah yang akan di bahas, yaitu :

1. Bagaimana membuat Sistem Informasi inventory Barang PadaPT. Exelindo Bintan Sejahtera Berbasis Desktop

\subsection{Batasan Masalah}

Agar penelitian ini lebih terarah, dan masalah tidak meluas dan terbatas nya waktu, dan efisiensi maka penulis membatasi permasalahan yang ada 
adapun batasan masalah yang dapat penulis uraikan yaitu:

1. Sistem yang dibangun hanya tentang pengelolaan data barang masuk dan keluar.

2. Sistem yang dibangun berbasis desktop.

3. Laporan hanya berupa inventory barang.

\subsection{Metode Pengembangan Perangkat Lunak}

Metode pengembangan perangkat lunak yang digunakan dalam membangun sistem informasi ini menggunakan model Waterfall (Classic Life Cycle) yang menyarankan pengembangan perangkat lunak secara sistematik dan berurutan yang dimulai dari tingkatan sistem tertinggi dan berlanjut ke tahap analisis, desain, pengkodean, pengujian dan pemeliharaan. Kelebihan dari metode ini adalah terstruktur, dinamis, dan sequential. Metode Waterfall dapat di lihat pada gambar 1 yang diambil oleh Adi Nugroho dari buku Object Oriented Programming With $\mathrm{C}++$ tulisan Balagurusamy (1999):

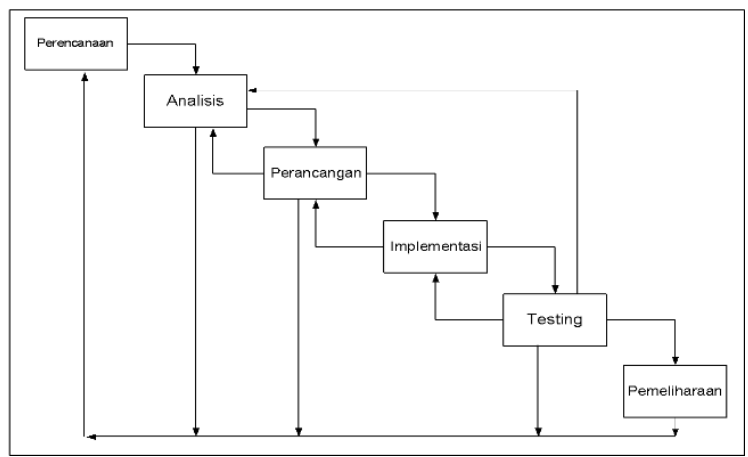

Gambar 1. Metode Waterfall $^{2}$

Paradigma dari tahapan model waterfall adalah sebagai berikut:

1. Perencanaan, apa yang dijelaskan pada bab ini yaitu menyangkut studi yang diperlukan pengguna, studi-studi layakan baik secara teknis maupun secara teknologi serta penjadwalan pengembangan suatu proyek sistem informasi dan atau perangkat lunak.

2. Analisis, yaitu tahap dimana kita berusaha mengenali segenap permasalahan yang muncul pada pengguna dengan mendekomposisi usecase diagram lebih lanjut, mengenali komponen-komponen sistem, obyek-obyek, hubungan antar obyek.

3. Perancangan, dimana kita mencoba mencari solusi permasalahan yang didapat dari tahap analisis. Tahap perancangan menekankan pada platform apa hasil dari tahap analisis kelak akan diimplementasikan.

4. Implementasi, dimana kita mengimplemtasikan perancangan sistem ke situasi yang nyata. Disini kita mulai berurusan dengan pemilihan perangkat keras, penyusunan perangkat lunak aplikasi (pengkodean atau coding).

5. Pengujian, apakah sistem yang kita buat sudah sesuai dengan kebutuhan pengguna atau belum. Jika belum, proses selanjutnya adalah iteratif, yaitu kembali ke tahap-tahap sebelumnya.

6. Pemeliharaan, dimana kita mulai melakukan pengoperasian sistem dan jika di perlukan melakukan perbaikan-perbaikan.

Pada tahapan ini merupakan aktivitas perencanaan dan perencanaan ini dibutuhkan untuk menentukan sumber daya. Perkiraan dari waktu pengerjaan dan informasi lainnya yang dibutuhkan untuk pengembangan software.

\section{Kajian Pustaka}

\subsection{Sistem Informasi}

Kata sistem berasal dari Bahasa Yunani yaitu Systema, yang dalam Bahasa Inggris dikenal dengan system, yang mempunyai satu pengertian yaitu sehimpunan bagian atau komponen yang saling berhubungan secara teratur dan merupakan satu keseluruhan yang tidak terpisahkan. Secara sederhana "sistem dapat di artikan sebagai suatu jaringan kerja dari prosedur-prosedur yang saling berhubungan, berkumpul bersama - sama untuk melakukan kegiatan atau menyelesaikan suatu sasaran tertentu"11. Secara sederhana sistem dapat diartikan sebagai suatu kumpulan atau himpunan dari unsur atau variabel-variabel yang saling terorganisasi, saling berinteraksi, dan saling bergantung sama lain. ${ }^{12}$ Menurut Hartono sistem adalah suatu kesatuan yang terdiri dua atau lebih komponen atau subsistem yang berinteraksi untuk mencapai suatu tujuan. ${ }^{13}$ Sedangkan informasi adalah data yang diolah menjadi bentuk yang lebih berguna dan lebih berarti bagi yang menerimanya. Dalam beberapa hal pengetahuan tentang peristiwa-peristiwa tertentu atau situasi yang telah dikumpulkan atau diterima melalui proses komunikasi yang didapatkan dari berita juga dinamakan informasi. ${ }^{14}$

Sebuah sistem informasi merupakan kumpulan dari perangkat keras dan perangkat lunak komputer serta perangkat manusia yang akan mengolah data menggunakan perangkat lunak dan perangkat keras tersebut. Selain itu, data juga memegang peranan penting dalam sistem informasi. Data yang akan dimasukkan dalam sebuah sistem informasi dapat berupa formulir-formulir, prosedur-prosedur dan bentuk data lainnya

\subsection{Metode FIFO(First In First Out)}

Barang yang pertama kali masuk (dibeli) menjadi barang yang pertama kali keluar (dijual). Masuk pertama keluar pertama Metode ini menyatakan bahwa persediaan dengan nilai perolehan awal (pertama) masuk akan dijual (digunakan) terlebih dahulu, sehingga persediaan akhir dinilai dengan nilai perolehan persediaan yang terakhir masuk (dibeli). Metode ini cenderung 
menghasilkan persediaan yang nilainya tinggi dan berdampak pada nilai aktivas perusahaan yang dibeli.

Metode FIFO merupakan metode penilaian persediaan yang sangat realistis dan cocok digunakan untuk semua sifat produk. Realistisnya terletak pada barang yang pertama kali dibeli, maka barang itulah yang pertama kali dijual. Jika perusahaan menggunakan metode FIFO dalam menilai persediaan dengan asumsi telah terjadi. ${ }^{5}$

\subsection{Persediaan}

Pengertian persediaan menurut Kasmir (2013: 264) adalah sejumlah barang yang harus disediakan oleh perusahaan pada suatu tempat tertentu. Artinya adanya sejumlah barang yang disediakan perusahaan guna memenuhi kebutuhan produksi atau penjualan barang dagangan. Sedangkan tempat tertentu dapat berupa gudang sendiri atau gudang pada perusahaan lain atau melalui pesanan yang pada saat dibutuhkan dengan harga yang telah disepakati dapat disediakan. Tidak dapat dipungkiri bahwa persediaan dapat membentuk hubungan antara produksi dengan penjualan. ${ }^{14}$

\section{Hasil dan Pembahasan}

\subsection{Perancangan Sistem}

Perancangan sistem merupakan tahap selanjutnya setelah analisis sistem, mendapatkan gambaran dengan jelas tentang apa yang dikerjakan pada analisis sistem, maka dilanjutkan dengan memikirkan bagaimana membentuk sistem tersebut.

Berdasarkan analisis yang telah dilakukan, maka akan dibangun sebuah aplikasi aplikasi inventory barang menggunakan metode FIFO yang dapat membantu P.T. Exelino dalam mengelola data stok barang pada P.T. Exelindo.

Perancangan sistem ini meliputi Flowchart, diagram konteks, Data Flow Diagram (DFD), Entity Relations Diagram (ERD), relasi antar tabel, perancangan struktur tabel, perancangan struktur program, perancangan struktur menu, perancangan input dan output ${ }^{3}$.

\subsection{Perancangan Struktur Tabel}

Berikut adalah perancangan struktur tabel pada database yaitu:

TABEL I

TABEL SUPPLIER

\begin{tabular}{ccccl}
\hline No & Nama Field & Tipe & Ukuran & \multicolumn{1}{c}{ Keterangan } \\
\hline $\mathbf{1}$ & Id & Int & 11 & Primary Key \\
$\mathbf{2}$ & Nama & Varchar & 20 & Nama Supplier \\
$\mathbf{3}$ & Alamat & Varchar & 255 & Alamat Supplier \\
$\mathbf{4}$ & Email & Varchar & 50 & Email Supplier \\
$\mathbf{5}$ & Telepon & Varchar & 50 & Kontak Supplier \\
\hline
\end{tabular}

TABEL II

TABEL PELANGGAN

\begin{tabular}{llll}
\hline No Nama Field & Tipe & Ukuran & Keterangan \\
\hline
\end{tabular}

\begin{tabular}{lcccl}
\hline $\mathbf{1}$ & Id & Int & 11 & Primary Key \\
$\mathbf{2}$ & Nama & Varchar & 20 & Nama Supplier \\
$\mathbf{3}$ & Alamat & Varchar & 255 & Alamat Supplier \\
$\mathbf{4}$ & Email & Varchar & 50 & Email Supplier \\
$\mathbf{5}$ & Telepon & Varchar & 50 & Kontak Supplier \\
\hline
\end{tabular}

\subsection{Flowmap Pemesanan Barang Usulan}

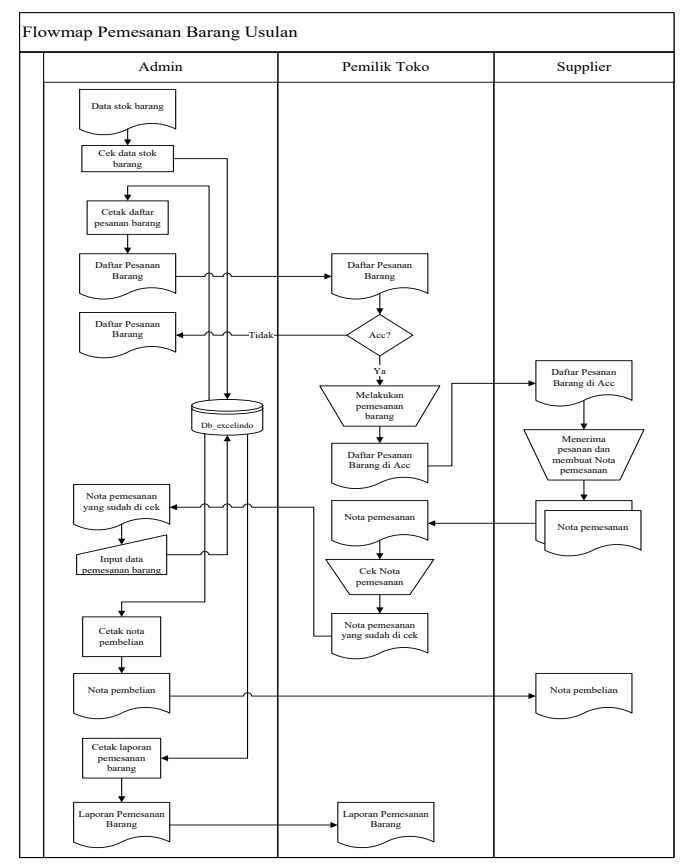

Gambar 2. Flowmap Pemesanan Barang Usulan

Prosedur Usulan Pemesanan Barang

1. Admin mengecek ketersediaan stok barang pada sistem.

2. Admin mecetak daftar pesanan barang dan diberikan kepada pemilik toko untuk ditanda tangan.

3. Jika pemiliki toko setuju, daftar pesanan ditanda tangan dan pemilik toko melakukan pemesanan barang ke supplier. Dan jika tidak setuju, daftar pesanan akan dikembalikan ke Admin.

4. Pemilik toko melakukan transaksi pemesanan barang kepada supplier dengan memberikan daftar pesanan yang sudah ditanda tangan.

5. Supplier menerima daftar pesanan yang diinginkan pemilik. Kemudian supplier memberikan nota pembelian kepada pemilik toko.

6. Pemiliki toko mengecek nota pemesanan dan di serahkan ke admin untuk diarsip.

7. Admin menginput data pemesanan barang pada sistem dan memcetak nota pembelian untuk diserahkan ke supplier.

\subsection{Flowmap Penjualan Barang Usulan}




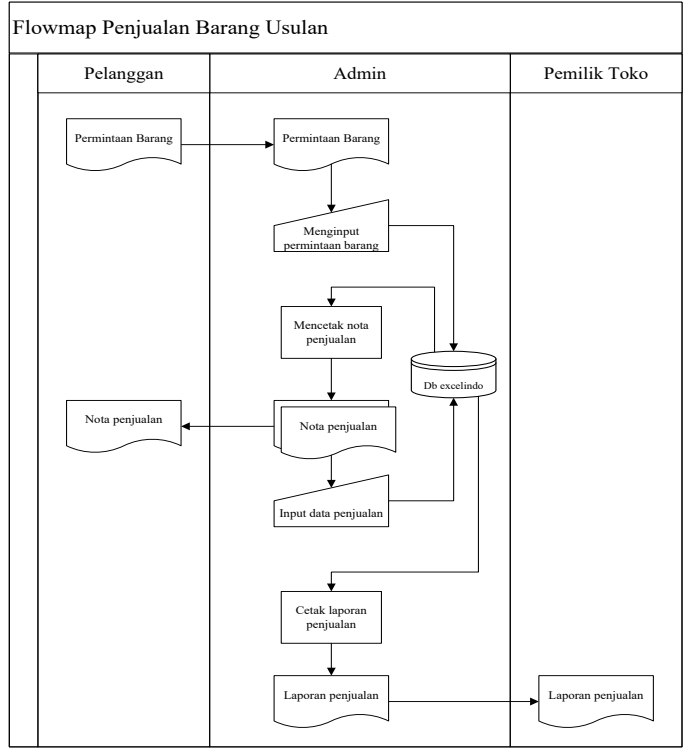

Gambar 3. Flowmap Penjualan Barang Usulan

Prosedur Usulan Penjualan Barang

1. Pembeli lokal datang ke took

2. Pembeli melihat-lihat barang yang tersedia, apabila ada barang yang dikehendaki maka melakukan permintaan barang.

3. Admin menginput permintaan barang pada sistem dan mencetak nota penjualan 2 rangkap, satu untuk pelanggan dan satu lagi diinput pada sistem.

4. Admin mencetak laporan penjualan untuk diserahkan kepada pemilik

\subsection{Diagram Konteks}

Diagram konteks merupakan gambaran secara umum mengenai sebuah sistem yang dirancang secara global, yaitu suatu diagram yang mempersentasikan atau menggambarkan hubungan antara sistem dengan luar lingkungan luar sistem yang mempengaruhi operasi sistem.

Sistem ditunjukan dalam satu lingkungan yang menggambarkan keseluruhan proses dalam sistem dan hubungannya dengan entitas. Berikut ini adalah gambaran perancangan sistem diagram konteks pada aplikasi inventori barang menggunakan metode FIFO ini:

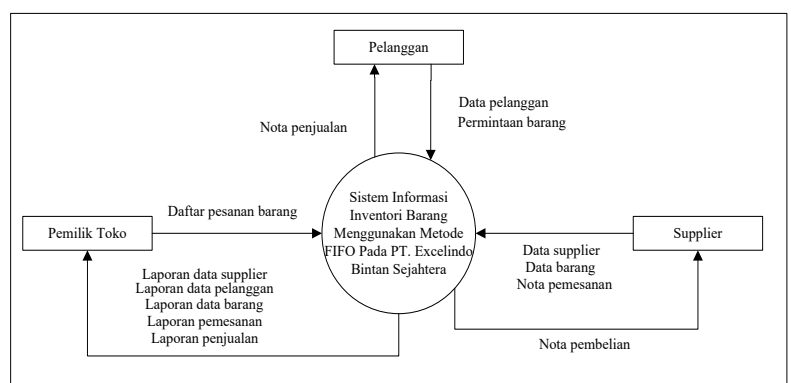

Gambar 4. Diagram Konteks

\subsection{DFD Level 0}

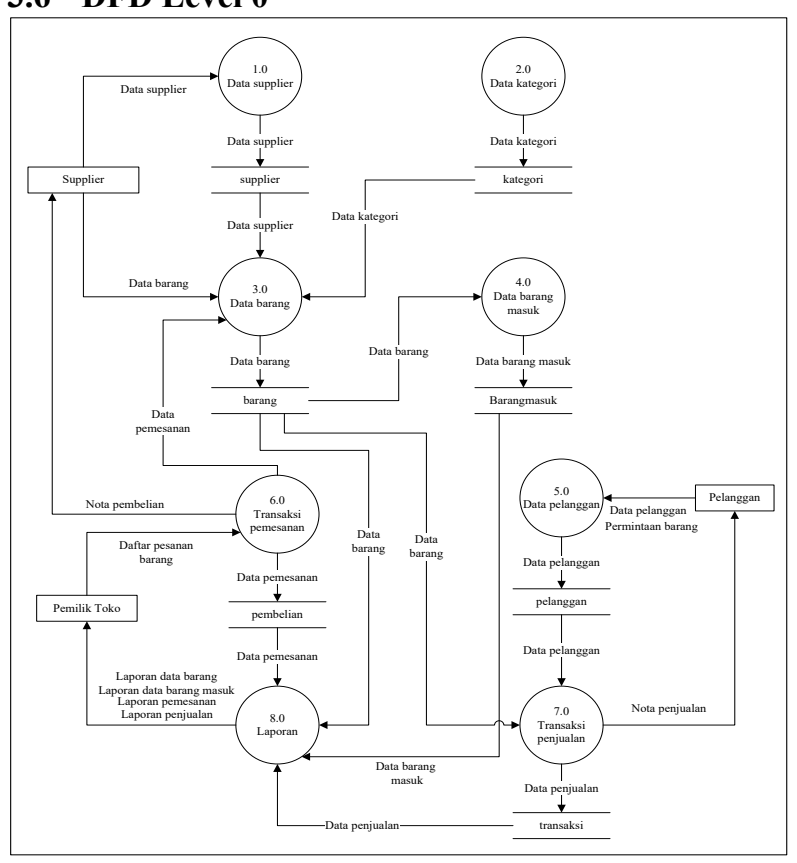

Gambar 5. Data Flow Diagram Level 0

Dari gambar DFD level 0 di atas dapat dibagi menjadi 8 proses, 8 proses tersebut dapat dijelaskan sebagai berikut:

1. Proses 1.0 adalah proses data supplier. Proses ini adalah proses pengolahan data supplier yang dilakukan untuk menginput data supplier yang diperoleh dari keterangan supplier tersebut.

2. Proses 2.0 adalah proses data kategori. Proses ini adalah proses pengolahan data kategori yang dilakukan untuk menginput data kategori barang yang diperoleh dari pemilik.

3. Proses 3.0 adalah proses data barang. Proses ini adalah proses pengolahan data barang yang dilakukan untuk menginput data barang yang belum ada di database dan diperoleh dari supplier.

4. Proses 4.0 adalah proses data barang masuk. Proses ini adalah proses pengolahan data barang masuk yang dilakukan untuk menginput data barang masuk beserta jumlah stoknya.

5. Proses 5.0 adalah proses data pelanggan. Proses ini adalah proses pengolahan data pelanggan yang dilakukan untuk menginput data pelanggan yang diperoleh dari keterang pelanggan tersebut.

6. Proses 6.0 adalah proses transaksi pemesanan. Proses ini adalah proses pengolahan data transaksi pemesanan barang kepada supplier, yang dilakukan dengan menginput data barang pesanan dari nota pemesanan yang didapat dari supplier.

7. Proses 7.0 adalah proses transaksi penjualan. Proses ini adalah proses pengolahan data transaksi penjualan barang kepada pelanggan, 
yang dilakukan dengan menginput data permintaan barang dari pelanggan.

8. Proses 8.0 adalah proses laporan. Proses ini adalah proses pencetakkan laporan data dari setiap proses.

\subsection{Entity Relationship Diagram (ERD)}

Entity relationship diagram (ERD) atau diagram antar entitas adalah suatu teknik permodelan data dengan diagram yang menggambarkan hubungan entitas dan relasi antar entitas dalam sebuah aplikasi. Berikut ini adalah peranan gambar ERD dalam aplikasi iinventory barang menggunakan metode FIFO:

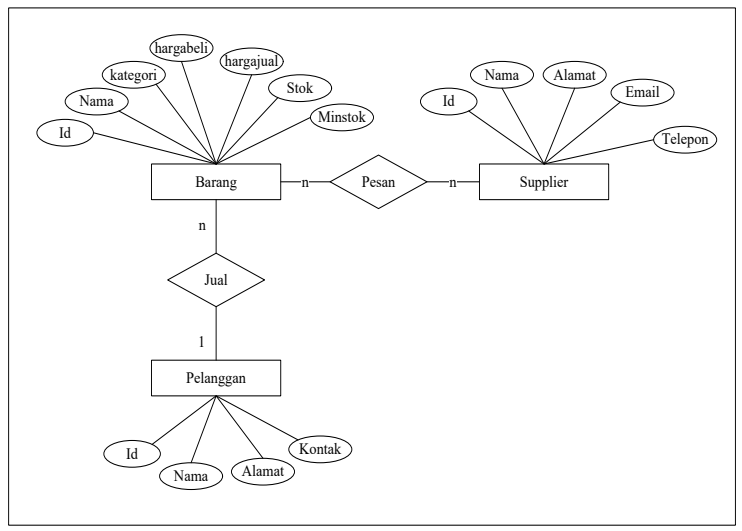

Gambar 6. Entity Relationship Diagram

\subsection{Implementasi Sistem}

Implementasi sistem merupakan tahap penerapan dan pengujian sistem supaya sistem siap untuk digunakan dan dijalankan. Sistem setelah dianalisis dan dirancang, maka sistem tersebut siap diterapkan atau diimplementasikan. Tahap implementasi ini dimana tahap sistem telah digunakan oleh pengguna. Sebelum benar-benar bisa digunakan dengan baik oleh pengguna, sistem harus melalui tahap pengujian terlebih dahulu untuk menjamin tidak ada kendala fatal yang muncul pada saat pengguna memanfaatkan sistemnya ${ }^{8}$.

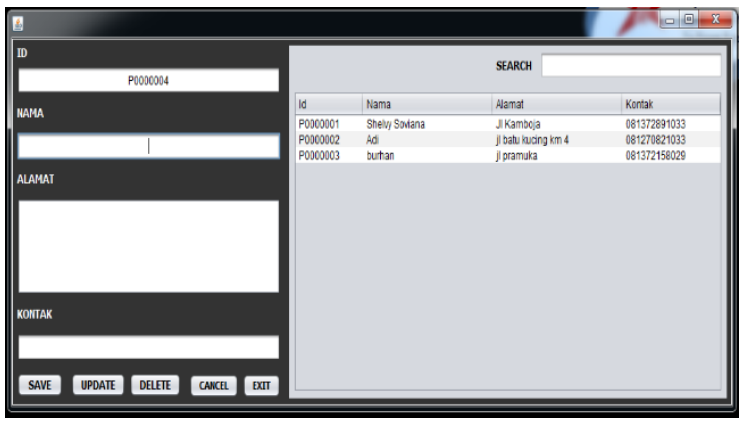

Gambar 7. Tampilan Input Data Pelanggan

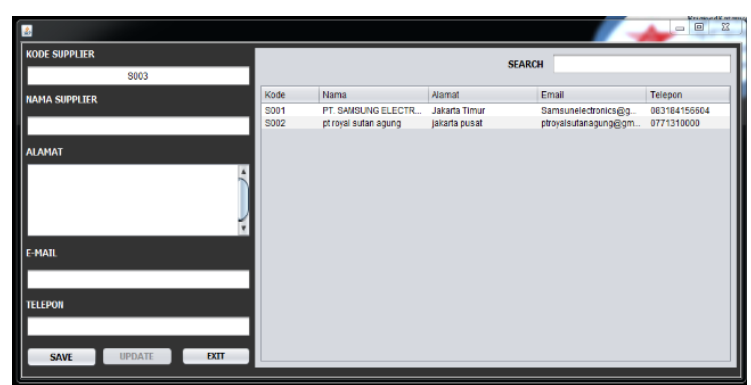

Gambar 8. Tampilan Input Data Supplier

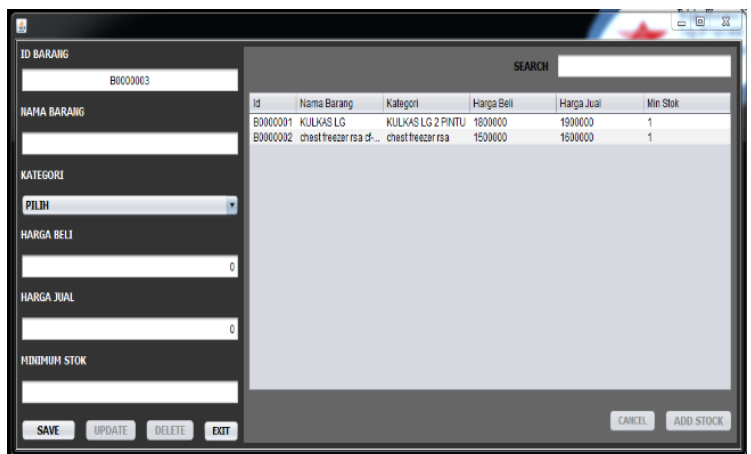

Gambar 9. Tampilan Input Data Barang

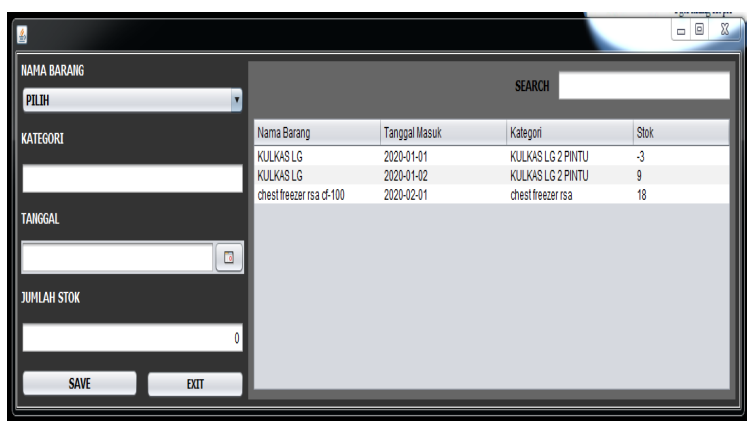

Gambar 10. Tampilan Input Barang Masuk

\section{Kesimpulan dan Saran}

\subsection{Kesimpulan}

Setelah merancang dan membangun aplikasi inventory barang menggunakan metode FIFO ini, maka dapat diambil beberapa kesimpulan adalah sebagai berikut:

a. Dengan adanya sistem inventory yang telah menggunakan metode FIFO ini diharapkan dapat membantu PT. Exelindo dalam mengelola inventory barang.

b. Dengan sistem ini, maka proses pembuatan laporan menjadi lebih rinci, sehingga bisa membantu PT. Exelindo dalam mengelola pembuatan laporan mereka

\section{Daftar Pustaka}

[1] Buku Panduan Penulisan laporan kerja praktek dan skripsi STTI 2014

[2] Andri Kristanto, Perancangan Sistem Informasi dan Aplikasinya (Edisi Revisi), Penerbit Gava Media, 2018, Yogyakarta. 
[3] Elvianna, Ricak Agus Setiawan, M.Faizal, Dedy Jauhari, M. Rizki Romdoni, Panduan TA 2014 STTI Tanjungpinang, 2014, Tanjungpinang.

[4] Hariyanto Bambang,M.T, Esensi-esensi Bahasa Pemograman JAVA, Informatika, 2003, Bandung.

[5] Hermawan, Sigit, Akuntansi Perusahaan Manufaktur, GRAHA ILMU, 2008, Yogyakarta.

[6] Indra Yatini B, Flowchart, Algoritma, dan Pemrograman Menggunakan Bahasa C++ Builder, Graha Ilmu, 2010, Yogyakarta.

[7] Nugroho Adi, Analisa dan Perancangan Sistem Informasi dengan Metode Berorientasi Objek, Informatika, 2004, Bandung.

[8] Nugroho Adi, Rekayasa Perangkat Lunak, CV Andi Offset, 2010, Yogyakarta.

[9] Sutabri Tata, Analisis Sistem Informasi, Andi, 2012, Yogyakarta

[10] Prof.Dr. Jogiyanto HM, MBA, Akt, Analisis dan Desain Sistem Informasi, 2004

[11] S. M. Metev and V. P. Veiko, Laser Assisted Microtechnology, 2nd ed., R. M. Osgood, Jr., Ed. Berlin, Germany: Springer-Verlag, 1998.

[12] J. Breckling, Ed., The Analysis of Directional Time Series: Applications to Wind Speed and Direction, ser. Lecture Notes in Statistics. Berlin, Germany: Springer, 1989, vol. 61.

[13] S. Zhang, C. Zhu, J. K. O. Sin, and P. K. T. Mok, "A novel ultrathin elevated channel lowtemperature poly-Si TFT," IEEE Electron Device Lett., vol. 20, pp. 569-571, Nov. 1999.

[14] Drs. Ali Mashar, MM., "Manajemen Operasional" http://mercubuana.ac.id/files/ManajemenOpera sional/MODUL $\% 2012 \% 20 \mathrm{MO} \% 20$ Persediaanok.pdf 